Research Article

\title{
Phytochemical Composition, Antioxidant, Antiacetylcholinesterase, and Cytotoxic Activities of Rumex crispus $\mathbf{L}$.
}

\author{
Mohamed Marouane Saoudi $\mathbb{D},{ }^{1,2}$ Jalloul Bouajila $\mathbb{D}^{2},{ }^{2}$ Rami Rahmani $\mathbb{D}^{2,3}$ \\ and Khaled Alouani ${ }^{1}{ }^{1}$ \\ ${ }^{1}$ Laboratoire de Chimie Analytique et Électrochimie, Faculté des Sciences de Tunis, Université de Tunis El Manar, \\ Campus Universitaire, Tunis 2092, Tunisia \\ ${ }^{2}$ Laboratoire de Génie Chimique, Université Paul Sabatier, CNRS, INPT, UPS, Toulouse, France \\ ${ }^{3}$ Unité de Recherche "Valorisation des Biomolécules Actives", Institut Supérieur de Biologie Appliquée de Médenine, \\ Route El Jorf-km 22.5, Medenine 4119, Université de Gabès, Gabès, Tunisia
}

Correspondence should be addressed to Khaled Alouani; khaled.alouani@gmail.com

Received 28 December 2020; Revised 14 June 2021; Accepted 22 June 2021; Published 3 July 2021

Academic Editor: Antonio V. Herrera-Herrera

Copyright (c) 2021 Mohamed Marouane Saoudi et al. This is an open access article distributed under the Creative Commons Attribution License, which permits unrestricted use, distribution, and reproduction in any medium, provided the original work is properly cited.

\begin{abstract}
Rumex crispus L. (R. crispus) is regarded as an aromatic plant. It was used for its excellent biological properties in traditional medicine. The aerial part was extracted successively by maceration with three solvents increasing polarity (cyclohexane (CYH), dichloromethane (DCM), and methanol $(\mathrm{MeOH})$ ) to evaluate their chemical compositions and biological activities. The extracts were rich in phenolic compounds ( 13.0 to $249.8 \mathrm{mg} \mathrm{GAE} / \mathrm{g}$ of dry weight (dw)). The $\mathrm{MeOH}$ extract has presented remarkable $\mathrm{IC}_{50}=6.2 \mu \mathrm{g} / \mathrm{mL}$ for anti-DPPH and $31.6 \mu \mathrm{g} / \mathrm{mL}$ for anti-AChE. However, the DCM extract has the highest cytotoxic activity against the two cancer cells (HCT-116 and MCF-7) $(69.2$ and $77.2 \%$ inhibition at $50 \mu \mathrm{g} / \mathrm{mL}$, respectively). Interestingly, GC-MS analysis enabled to identify three new compounds in R. crispus extracts, such as L-(-)-arabitol (5), D-(-) fructopyranose (7) detected only in $\mathrm{MeOH}$ extract, and 2, 5-dihydroxyacetophenone (3) detected in all extracts. For HPLC chromatograms, cardamonin (8), 5-hydroxy-3'-methoxyflavone (17), and 3'-hydroxy-b-naphthoflavone (18) showed the highest concentrations of $74.0,55.5$, and $50.4 \mathrm{mg} / \mathrm{g}$ of $\mathrm{dw}$, respectively, among others who are identified. Some phenolic compounds were identified and quantified by HPLC in more than one organic extract, such as $4^{\prime}$, 5-dihydroxy-7-methoxyflavone (13), 4', 5-dihydroxy-7methoxyflavone (14), 5-hydroxy-3'-methoxyflavone (17), and $3^{\prime}$-hydroxy-b-naphthoflavone (18), were found for the first time in the $R$. crispus extracts. Our results showed that the biological activities of this plant might be linked to their phenolic compounds and that the polar extracts could be considered as new natural supplements to be used in food and pharmaceuticals.
\end{abstract}

\section{Introduction}

Excessive free radical production and lipid peroxidation represent an important role in some pathogenesis of serious diseases, such as diabetes, acquired immunodeficiency syndrome, neurodegenerative diseases, cardiovascular disease, cancer, cirrhosis of the liver, ischemia, atherosclerosis, and aging [1,2]. Approximately $95 \%$ of the pathologies detected in humans over the age of 35 are associated with the production and accumulation of free radicals [3]. These toxic radicals can be obtained either through biochemical or physiological processes or through pollution and other endogenous sources. In fact, they are capable of reacting with membrane lipids, nucleic acids, proteins and enzymes, and certain molecules, leading to bad cellular consequences [4].

Plants can give several antioxidant compounds such as flavonoids, phenolic acids, and $a$-tocopherol, which help the human body to neutralize free radicals in a synergistic and interactive way. For this reason, these compounds are more 
considered as important dietary factors $[2,5]$. In fact, it has been noted that foods rich in antioxidants have an inverse relationship with the incidence of human disease [6]. Since the use of synthesized antioxidants promotes negative health effects, a vision has led researchers to replace them with natural antioxidants [7] to valorize the raw materials of certain plants by identifying their new powerful compounds, which can be used as an herbal medicine for certain diseases. Tunisia has a wide variety of species with multiple interests, including popular therapeutic practices. Some plants for each species have not been subjected to chemical studies [8]. Approximately 200 species of plants in the genus Rumex are characterized by their edible and medicinal virtues [9]. These species contain many bioactive compounds with complex chemical structures. The aerial and roots parts of different plants belong to the Polygonaceae family, including Rumex, have been used as a natural source of traditional medicines in several therapeutic uses, such as anti-inflammatory, antioxidants, antianalgesic, and antimicrobial activities $[10,11]$. They are also used for the treatment of certain diseases like cancer, tumor, and diseases related to liver and urinary/kidney functions $[12,13]$. There are some reports in the literature about the evaluation of some species of Rumex which have exhibited health-promoting effects and have been used as traditional foods and herbal remedy. For example, stems, leaves, and roots of $R$. abyssinicus L., $R$. bequaertii L., and $R$. usambarensis $\mathrm{L}$. are used to treat coughs, pneumonia, abscesses, smallpox, and upset stomach [14]. In addition, $R$. nepalensis L. roots have shown significant antibacterial activity against Staphylococcus aureus, Bacillus subtilis, and Escherichia coli [15]. In a recent study, roots from $R$. hastatus D. showed interesting antimicrobial, cytotoxic, and antitumor activities [16]. Moreover, in the spring, the aerial parts of many species (R. crispus, R. acetosa, $R$. pseudonatronatus $R$. patientia, and $R$. acetosella) are collected and used as vegetables [17].

Rumex crispus, commonly named "curled dock" because of the wavy and curly leaves, is a perennial plant which growing wild (native) in the most of European area, Central and East Asia, and North African regions, including Tunisia $[18,19]$. It grows well in disturbed soil, roadsides, shorelines, and forest edges and can reach $1.20 \mathrm{~m}$ of tall with a fleshy taproot $[20,21]$. Despite being considered an invasive plant in several countries (North American, New Zealand, and Australia) [22], the curly dock is regularly used in traditional medicine as a useful alternative in Siberian and Turkish traditional medicine. It is useful as a drug intended for the treatment of venereal diseases and used synonymously with "blood purifier" [18]. Furthermore, young leaves of $R$. crispus are edible, and they can be consumed eaten as a potherb or raw as a vegetable, especially in the spring, added to the salads [21]. However, the physiological or chemical evidence supporting any claim of therapeutic value for $R$. crispus that we can find in Tunisia and in some Mediterranean countries [23].

Therefore, in this work, phytochemical screening (TPC, HPLC, and GC-MS) and antioxidant evaluation and the biological activities (anti-AChE and cytotoxicity) of $R$. crispus extracts were carried out.

\section{Materials and Methods}

2.1. Chemicals Used. All chemicals used were of analytical reagent grade. All reagents were purchased from Sigma, Aldrich: Ascorbic acid, Acetic acid, acetylcholinesterase (AChE), acetylthiocholine (ACTHI) acetonitrile (ACN), N, O-bis (trimethylsilyl) trifluoroacetamide (BSTFA), cyclohexane (CYH), dichloromethane (DCM), Dulbecco's modified eagle medium (DMEM), dimethyl sulfoxide (DMSO), 1-1-diphenyl-2-picryl hydrazyl (DPPH), 5, 5dithiobis-2-nitrobenzoic acid (DTNB), Folin-Ciocalteu reagent $(2 \mathrm{~N})$, methanol $(\mathrm{MeOH})$, human colon cancer cells (HCT116), human breast cancer cells (MCF-7), 3- [4, 5dimethylthiazol-2yl]-2, 5-diphenyl tetrazolium bromide (MTT), Roswell Park Memorial Institute (RPMI), Chlorotrimethylsilane (TMCS), and tetrahydrofuran (THF).

The analytical standards used for the identification and quantification of the principal phenolic compounds found in the extracts: 3-amino-4-hydroxybenzoic acid, Gallic acid, 3, 4-dihydroxy-5 methoxybenzoic acid, 7-hydroxycoumarin3-carboxylic acid, rutin hydrate, Butyl gallate, 4-hydroxytamoxifen, cardamonin, phenoxodiol, pinostilbene hydrate, 3-benzyloxy-4, 5-dihydroxy-benzoic acid methyl ester, ethyl trans-2-hydroxycinnamate, 4', 5-dihydroxy-7methoxyflavone, pinosylvin monomethyl ether, 3, 6, 3'trimethoxyflavone, shikonin, 5-hydroxy-3'-methoxyflavone, and $3^{\prime}$-hydroxy-b-naphthoflavone were also purchased from Sigma, Aldrich.

2.2. Plant Material. The aerial part (stems, leaves, and flowers) of R. crispus was collected from the locality of BorjCedria (Northern Tunisia). The plant was harvested in September 2014, corresponding to its full bloom period. Then, the harvested plant was identified at the center of biotechnology of Borj-Cedria (CBBC), and a voucher specimen was placed at the herbarium of the laboratory of the ecoprocesses in the same center cited.

2.3. Preparation of Different Extracts. The plant material was dried in the shade at room temperature. Grinding was carried out to obtain a fine powder. For the extraction of the metabolites, fifty grams $(50 \mathrm{~g})$ were subjected to successive exhaustion using solvents of increasing polarity (cyclohexane (CYH), dichloromethane (DCM), and methanol $(\mathrm{MeOH})$ ) by maceration and stirring at room temperature in a volume of $500 \mathrm{~mL}$ and for 2 hours for each solvent. After filtration using Whatman $\mathrm{N}^{\circ} 2$ filter paper (Fisher, France), the filtrates were evaporated using a vacuum rotary evaporator at $35^{\circ} \mathrm{C}$ (IKA, Germany). This protocol enabled us to obtain the $\mathrm{CYH}, \mathrm{DCM}$, and $\mathrm{MeOH}$ dry extracts. These extracts were stored at $-4^{\circ} \mathrm{C}$ until further analysis (phytochemical and biological analysis). The extraction yield was characterized as follows:

$$
R(\%)=\left(\frac{m_{\text {residue }}}{m}\right) \times 100,
$$

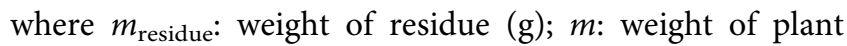
material $(\mathrm{g})$. 
2.4. Determination of Total Phenolic Content. According to the Folin-Ciocalteu colorimetric method, the total phenolic compound content in the extract was evaluated, and some modifications were made [24]. In short, add $100 \mu \mathrm{L}$ of Folin-Ciocalteu reagent $(0.2 \mathrm{~N})$ to $20 \mu \mathrm{L}$ of diluted extract $(0.5 \mathrm{mg} / \mathrm{mL}) /$. After incubating for 5 minutes at room temperature $\left(20-27^{\circ} \mathrm{C}\right)$, add $80 \mu \mathrm{L}$ of sodium carbonate solution $(75 \mathrm{~g} / \mathrm{L}$ in water). The blend was then incubated for 15 minutes, and the absorbance was measured at $765 \mathrm{~nm}$, using a microplate reader (Multiskan GO, Thermo Fisher Scientific, Vantaa, Finland). Gallic acid was used as a standard reference substance for the calibration curve $(0-115 \mathrm{mg} / \mathrm{L})$. The results were expressed as $\mathrm{mg}$ of gallic acid equivalents (GAE)/g of $\mathrm{dw}$.

2.5. DPPH Scavenging Activity of Free Radicals. The 1-1diphenyl-2-picryl hydrazyl (DPPH) test was used to measure antioxidant activity. The quantitative estimate of the scavenging capacity of free radicals was determined according to the method described by Yahyaoui et al. [24]. This mixture was homogenized and incubated $25 \mathrm{~min}$ in the dark at room temperature. Then, the absorbance of all samples was measured at $524 \mathrm{~nm}$. The percentage of inhibition percent of the free radical scavenging activity of each sample was calculated as follows:

$$
\% \text { inhibition }=\left[\frac{A_{\text {blank }}-A_{\text {sample }}}{A_{\text {blank }}}\right] * 100,
$$

where $A_{\text {blank }}$ is the absorbance of the negative control reaction without extract. $A_{\text {sample }}$ is the absorbance of the test sample.

This activity was also expressed as $\mathrm{IC}_{50}(\mathrm{mg} / \mathrm{L})$, which represents the concentration of test material required to promote a $50 \%$ decrease in the initial concentration of $\mathrm{DPPH}$. All measurements were performed in triplicate using ascorbic acid as a reference.

\subsection{Chromatographic Analysis}

2.6.1. HPLC-DAD Analysis. Using the method of Yahyaoui et al. [24] with a C18 column $(25 \mathrm{~cm} \times 4.6 \mathrm{~mm} \times 5 \mu \mathrm{m})$, the different extracts of $R$. crispus were analyzed on analytical HPLC-DAD (Thermo Fisher Scientific, USA). Using a mobile phase composed of acidified water $(\mathrm{pH}=2.65)$ (solvent A) and water/acetonitrile $(20: 80 v / v, \mathrm{pH}=2.65)$ (solvent B), elution was performed at a flow rate of $1.2 \mathrm{~mL} /$ min. The limit of detection (LOD) of the method was defined from $0.01-0.1 \mathrm{mg} / \mathrm{L}$. The gradient proceeds as follows: from $0.1 \%$ to $30 \% \mathrm{~B}$ in 35 minutes, from $30 \%$ to $50 \% \mathrm{~B}$ in 5 minutes, from $50 \%$ to $99.9 \% \mathrm{~B}$ in 5 minutes, and finally from $99.9 \%$ to $0.1 \%$ B in 15 minutes. To detect most compounds, all samples were prepared at the same concentration $(20 \mathrm{mg} /$ $\mathrm{mL})$. After injecting twenty microliters $(20 \mu \mathrm{L})$ of each sample, they were detected at $280 \mathrm{~nm}$. The phenolic compounds can be determined by comparing the retention time of the unknowns with the standards with known retention time.
2.6.2. GC-MS Analysis. Gas chromatography-mass spectrometry (GC-MS) analysis was carried out using Varian Saturn 2000 (Les Ulis, France) ion trap GC/MS and CP3800 GC system equipped with fused silica capillary DB5MS column (5\% phenylmethyl Polyoxane, $30 \times 0.25 \mathrm{~mm}$, film Thickness $0.25 \mu \mathrm{m}$ ) [25]. Chromatographic conditions were $60-260^{\circ} \mathrm{C}$, and the temperature was increased in a gradient of $5^{\circ} \mathrm{C} / \mathrm{min}$ and continued for 15 minutes under isothermal conditions of $260^{\circ} \mathrm{C}$. Apply a second gradient to reach $340^{\circ} \mathrm{C}$ at a rate of $40^{\circ} \mathrm{C} / \mathrm{min}$. The temperature of the trap was $250^{\circ} \mathrm{C}$ and the temperature of the transmission line was $270^{\circ} \mathrm{C}$. Perform quality scans from 40 to $650 \mathrm{~m} / \mathrm{z}$. The extract was dissolved in its extraction solvent in an amount of $5 \mathrm{mg} / \mathrm{mL}$, and $2 \mu \mathrm{L}$ was injected. The molecules were identified by comparing the retention index (RI) obtained on a nonpolar DB-5MS column versus C5-C24 n-alkanes with compounds provided in the literature and comparing their mass spectra with the NIST 08 (National Institute of Standards and Technology) database.

(1) Derivatization Method. Rahmani et al. [25] described the derivatization method and made some modifications. In a $2 \mathrm{~mL}$ vial, mix $150 \mu \mathrm{L}$ of $99 \% \mathrm{~N}$, O-bis (trimethylsilyl) trifluoroacetamide (BSTFA) $+1 \%$ of chlorotrimethylsilane (TMCS) with $1 \mathrm{~mL}$ of extract $(5 \mathrm{mg} / \mathrm{mL}$ in tetrahydrofuran (THF) solvent). After that, the blend was mixed for 30 seconds to increase solubility. The reaction mixture was kept at $40^{\circ} \mathrm{C}$ for 15 minutes. Then, ten microliters $(10 \mu \mathrm{L})$ of each derivative solution was injected into the same GC-MS equipment and analyzed as described in the previous section to identify the molecules of each extract.

\subsection{Biological Activities}

2.7.1. Antiacetylcholinesterase (AChE) Activity. The antiAChE activity was determined according to the Ellman method [25]. In short, $25 \mu \mathrm{L}$ of each extract was mixed with $50 \mu \mathrm{L}$ of sodium phosphate buffer $(0.1 \mathrm{M}$; pH=8), $25 \mu \mathrm{L}$ of AChE solution and $125 \mu \mathrm{L}$ of 5, 5-dithiobis-2-nitrobenzoic acid (DTNB) $(3 \mathrm{mM}, \mathrm{pH}=7)$. The mixture was added to a 96-well microplate and incubated at $25^{\circ} \mathrm{C}$ for 15 minutes. After that, $25 \mu \mathrm{L}$ of ACTHI iodide solution $(15 \mathrm{mM})$ was added and the final mixture was incubated again at $25^{\circ} \mathrm{C}$ for 10 minutes. The absorbance of the yellow complex (5-thio-2nitrobenzoate anion) was read at $412 \mathrm{~nm}$. The concentration of the extract that caused $50 \%$ inhibition of AChE activity $\left(\mathrm{IC}_{50}\right)$ was calculated by nonlinear regression analysis. The percentage of inhibition was calculated as follows:

$$
\% \text { inhibition }=\left[\frac{A_{\text {blank }}-A_{\text {sample }}}{A_{\text {blank }}}\right] * 100,
$$

where $A_{\text {sample }}$ and $A_{\text {control }}$ were the absorbance of sample with the test material and of sample without the enzyme, respectively. Galantamine was used as a reference.

2.7.2. Cytotoxic Activity. The in vitro cytotoxic activity of different extracts on two different human cell lines, MCF-7 (human breast cancer cells) and HCT-116 (human colon 
cancer cells), was evaluated according to the method as described by Rahmani et al. [25]. This activity was estimated by MTT colorimetric test. Cells were distributed in 96-well plates at $3 \times 10^{4}$ cells/well in $100 \mu \mathrm{L}$ and added $100 \mu \mathrm{L}$ of the corresponding culture medium (DMEM, Sigma Aldrich, USA) for MCF-7 or RPMI-1640 (Sigma Aldrich, USA) for HCT-116 to each well, which contains samples of various concentrations. The plate was then incubated for $48 \mathrm{~h}$ at $37^{\circ} \mathrm{C}$. Next, the supernatant was then eliminated, and cells were treated with $50 \mu \mathrm{L}$ of MTT solution during $40 \mathrm{~min}$ of incubation at $37^{\circ} \mathrm{C}$. Then after the elimination of the MTT solution, $50 \mu \mathrm{L}$ of dimethyl sulfoxide (DMSO) was added to dissolve insoluble formazan crystal. The absorbance was measured at $605 \mathrm{~nm}$. The tamoxifen was used as a positive reference. The cytotoxic effect of the extract was estimated based on the percentage of growth inhibition and calculated as follows:

$$
\% \text { inhibition }=\left[\frac{A_{\text {blank }}-A_{\text {sample }}}{A_{\text {blank }}}\right] * 100 .
$$

2.8. Statistical Analysis. All measurements were performed in quadruplicate by one-way analysis of variance (ANOVA) using the SPSS (Version 20.0) for the significance calculation and the Tukey's test was used to estimate the statistical differences between the solvents used in the study. The linear correlation coefficient $\left(R^{2}\right)$ was examined to determine the rapport between the biological activities or antioxidant and the (TPC). Finally, the Principal Component Analysis (PCA) was also performed using XLSTAT (version 5.03) to visualize the difference between all the parameters. The reliability limits were set at $p \leq 0.05$.

\section{Results and Discussion}

3.1. Extraction Yields and Total Phenolic Content (TPC). In this study, three solvents with different polarities, namely: $\mathrm{CYH}, \mathrm{DCM}$, and $\mathrm{MeOH}$ were used for the extraction of the aerial part of $R$. crispus. Table 1 showed the yield obtained from different extracts. While the $\mathrm{MeOH}$ was highlighted the highest yield with $12.2 \%$, the extraction yield of both CYH and DCM does not exceed 1.0\%. These results were in agreement with those found by Idris et al. [21], who reported that maximum extract yield from $R$. crispus, collected in South Africa, was obtained with $\mathrm{MeOH}$ solvent. This yield was lower than that found in this study. The difference in the extract yield from the different extracts might be related to the availability of the extractable components.

As for the TPC of $R$. crispus extracts, it was ranged between 13.0 and $249.8 \mathrm{mg} \mathrm{GAE} / \mathrm{g}$ of $\mathrm{dw}$. A significant difference ( $p \leq 0.05$ ) between the different solvents used. The difference in TPC noticed between different solvents may be due to the polarity of phenolic compounds. A low TPC was obtained with the CYH and DCM extracts, which showed a content of 13.0 and $21.6 \mathrm{mg} \mathrm{GAE} / \mathrm{g}$ of $\mathrm{dw}$, respectively. However, the highest content was obtained with $\mathrm{MeOH}$ extract (249.8 $\mathrm{mg} \mathrm{GAE} / \mathrm{g}$ of $\mathrm{dw}$ ). This result was higher than those measured in the $\mathrm{MeOH}$ extract (56.3 $\mathrm{mg} \mathrm{GAE} / \mathrm{g}$ of dw)
TABLE 1: Yields and TPC in the aerial part of $R$. crispus extracts.

\begin{tabular}{lcc}
\hline Samples & Yields (\%) & TPC (mg GAE/g of dw) \\
\hline CYH & $1.0^{\mathrm{b}}$ & $13.0 \pm 0.3^{\mathrm{b}}$ \\
$\mathrm{DCM}$ & $0.3^{\mathrm{c}}$ & $21.6 \pm 0.5^{\mathrm{b}}$ \\
$\mathrm{MeOH}$ & $12.2^{\mathrm{a}}$ & $249.8 \pm 9.9^{\mathrm{a}}$ \\
\hline
\end{tabular}

CYH: cyclohexane; DCM: dichloromethane; $\mathrm{MeOH}$ : methanol. nd: not detected. Data are the mean of three repetitions \pm SD. Different letters indicate significant differences according to Tukey test $(p \leq 0.05)$.

in the study of Coruh et al. [26] when working with the aerial part of R. crispus growing wild in Turkey.

3.2. Antioxidant Activity. DPPH is one of the most used radicals to indicate the antioxidant activity possessed by both food and extracts. The antioxidant capacity of extracts from the aerial part of R. crsipus was measured by the method of $\mathrm{DPPH}$. The results were reported as the percentage of scavenged $\mathrm{DPPH}$ free radical and as the $\mathrm{IC}_{50}$ (Table 2). Statistically, there was a significant difference $(p \leq 0.05)$ between the different extracts in terms of antioxidant activity. Similar to the total phenolics, $\mathrm{MeOH}$ extract presented a major DPPH scavenging activity. This extract showed a high antioxidant activity of $93.5 \%$ at the concentration of $50 \mu \mathrm{g} / \mathrm{mL}$ with an $\mathrm{IC}_{50}$ value of $6.2 \mu \mathrm{g} / \mathrm{mL}$. The results were compared to the commercial antioxidant (ascorbic acid) $\left(\mathrm{IC}_{50}=3.9 \mu \mathrm{g} / \mathrm{mL}\right)$. However, $\mathrm{DCM}$ and $\mathrm{CYH}$ extracts showed a feeble ability to neutralize DPPH free radicals, with an inhibition percentage that did not exceed $30 \%$. These results indicate that the highest DPPH activity of the $\mathrm{MeOH}$ extract is closely related to the high content of phenolics. This was validated in our work by a high correlation between TPC and DPPH activity $\left(R^{2}=0.98\right)$.

Compared to the literature, the present results were higher compared to those found by Ćebović et al. [27]. They found that the water extract of R. cripus fruit has low DPPH activity, with a high $\mathrm{IC}_{50}=46 \mu \mathrm{g} / \mathrm{mL}$. However, the study of Elzaawely et al. [28], when working with Rumex japonicas aerial part, was not in accordance with our findings. They found that the EtOAc extract (moderately polar solvent) revealed the highest antioxidant activity.

\subsection{Chemical Composition of R. crispus Extracts}

3.3.1. HPLC-DAD Analysis. The identification of the phenolic compounds in the different extracts of the aerial part of $R$. crispus was made using the HPLC-DAD (Figure 1). For each chromatogram and based on the comparison of the retention time and DAD spectra of the standard compound analyzed under the same conditions, many phenolic compounds were identified. In total, 18 phenolic compounds were identified and quantified in all the extracts by means of their relative retention time (Table 3 ). Interestingly, the compounds which showed the highest concentrations belong to flavone and cardamonin classes. These compounds are cardamonin (8), 5-hydroxy- $3^{\prime}$-methoxyflavone (17), and $3^{\prime}$-hydroxy-b-naphthoflavone (18), detected in the DCM extract, with a concentration of $74.0,55.5$, and $50.4 \mathrm{mg} / \mathrm{g}$ of 
TABLE 2: Antioxidant activity of the areal part of $R$. crispus extracts.

\begin{tabular}{|c|c|c|}
\hline \multirow{2}{*}{ Samples } & \multicolumn{2}{|c|}{ Antioxidant activity (DPPH) } \\
\hline & $\%$ Inhibition $(50 \mu \mathrm{g} / \mathrm{mL})$ & $\mathrm{IC}_{50}(\mu \mathrm{g} / \mathrm{mL})$ \\
\hline $\mathrm{CYH}$ & $14.3 \pm 2.0^{\mathrm{c}}$ & $>50$ \\
\hline DCM & $29.3 \pm 1.6^{\mathrm{b}}$ & $>50$ \\
\hline $\mathrm{MeOH}$ & $93.5 \pm 1.0^{\mathrm{a}}$ & $6.2 \pm 3.0$ \\
\hline Ascorbic acid & - & $3.9 \pm 0.1$ \\
\hline
\end{tabular}

CYH: cyclohexane; DCM: dichloromethane; $\mathrm{MeOH}$ : methanol. Data are the mean of three repetition \pm SD. Different letters indicate significant differences according to the Tukey's test $(p \leq 0.05)$.

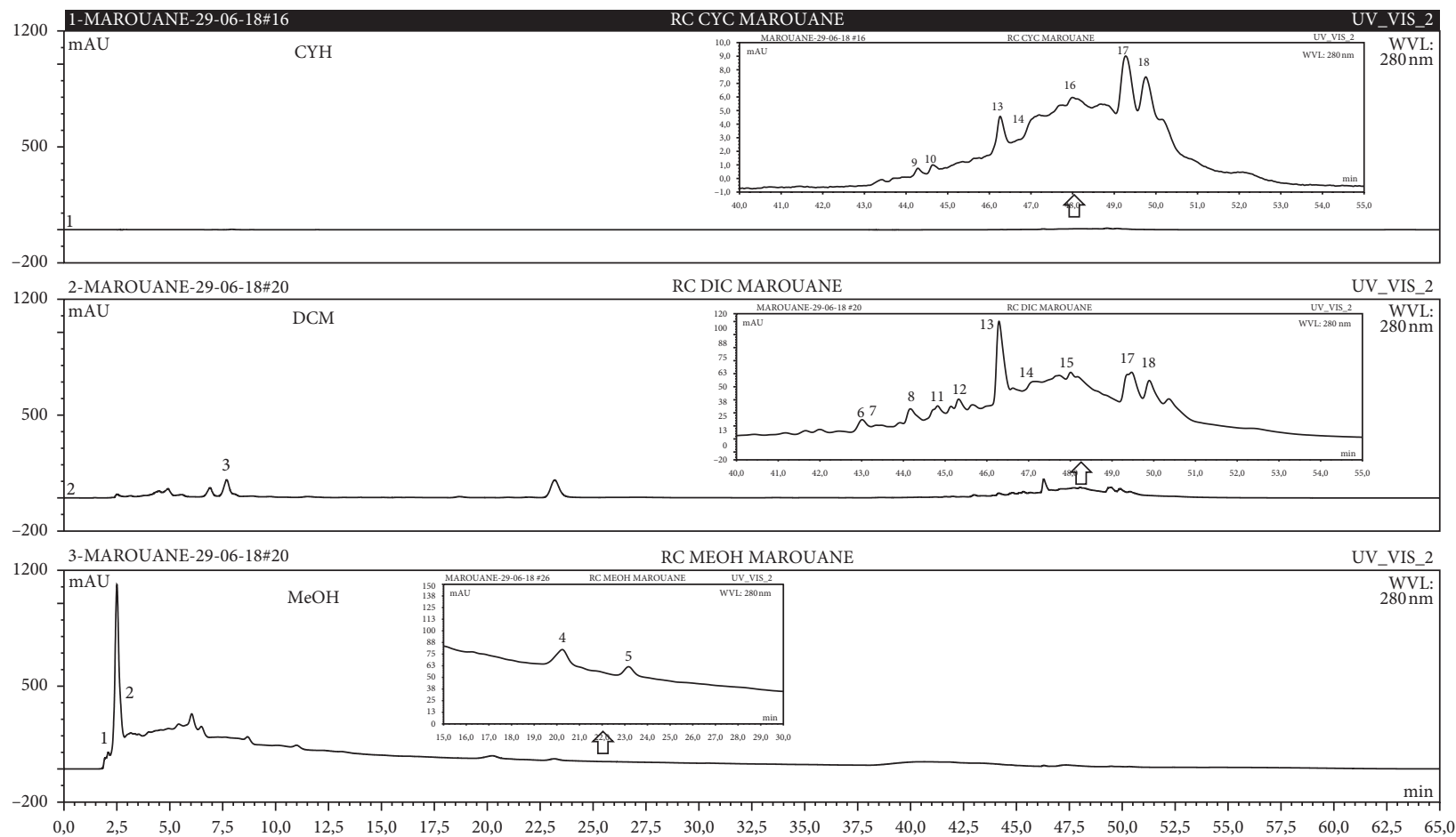

FIGURE 1: HPLC chromatograms profiles, visualized at $280 \mathrm{~nm}$, of. (CYH: cyclohexane; DCM: dichloromethane and MeOH: methanol) extracts obtained from aerial parts of $R$. crispus collected from Tunisia. Peaks: (1) 3-amino-4-hydroxybenzoic acid; (2) gallic acid; (3) 3, 4dihydroxy-5 methoxybenzoic acid; (4) 7-hydroxycoumarin-3-carboxylic acid; (5) rutin hydrate; (6) butyl gallate; (7) 4-hydroxytamoxifen; (8) cardamonin; (9) phenoxodiol; (10) pinostilbene hydrate; (11) 3-benzyloxy-4, 5-dihydroxy-benzoic acid methyl ester; (12) ethyl trans-2hydroxycinnamate; (13) 4', 5-dihydroxy-7-methoxyflavone; (14) pinosylvin monomethyl ether; (15) 3, 6, 3'-trimethoxyflavone; (16) shikonin; (17) 5-hydroxy-3'-methoxyflavone; (18) 3'-hydroxy-b-naphthoflavone.

dw, respectively. Besides, with moderate concentrations, we found other compounds belong to flavone and benzoic acid classes such as $4^{\prime}$, 5-dihydroxy-7-methoxyflavone (13) $(25.0 \mathrm{mg} / \mathrm{g}$ of $\mathrm{dw}), 3,6,3^{\prime}$-trimethoxyflavone $(\mathbf{1 5})(19 \mathrm{mg} / \mathrm{g}$ of $\mathrm{dw}$ ), and 3, 4-dihydroxy-5 methoxybenzoic acid (3) $(15.3 \mathrm{mg} / \mathrm{g}$ of $\mathrm{dw})$. All these phenolic compounds were found for the first time in $R$. crispus extracts.

The HPLC chromatograms showed that the chemical composition changes significantly according to the polarity of the solvent used. Therefore, the CYH extract contains more nonpolar phenolic compounds and their elution process has occurred at the end of acquisition. For the DCM extract, both the polar and nonpolar compounds can be identified as having a maximum intensity equal to $110 \mathrm{mV}$.

The polar extract $(\mathrm{MeOH})$ had more polar compounds eluted between 2 and $20 \mathrm{~min}$ compared to the other two extracts with a maximum intensity equal to $650 \mathrm{mV}$. It can be deduced that the intensity of the peaks increased with the polarity of the solvent, which can confirm the results of TPC (Table 1). In other words, the HPLC-DAD results were strongly correlated with the results found by the colorimetry test and confirm the richness of the extract by the phenolic compounds. By comparing with the literature, some phenolic compounds found in the extract of $R$. cripus were discovered for the first time, such as $4^{\prime}$, 5-dihydroxy-7methoxyflavone (13), 5-hydroxy-3'-methoxyflavone (17), and $3^{\prime}$-hydroxy-b-naphthoflavone (18). However, other compounds were previously detected, such as gallic acid detected in $R$. acetosa (Kucekova et al. [46], and cardamonin detected in Polygonum ferrugineum [47]. Cardamonin has received serious attention from scientific researchers due to the expectation that it is beneficial to human health [36]. 
TABLE 3: Phenolic compounds contents identified in various extracts of $R$. crispus aerial parts by HPLC-DAD.

\begin{tabular}{lll}
\hline $\mathrm{N}^{\circ} \quad$ Compounds and chemical structure compounds & Rt (min) $\begin{array}{c}\text { Concentration } \\
(\mathrm{mg} / \mathrm{g} \text { of dw) } \\
\mathrm{CYH} \mathrm{DCM} \mathrm{MeOH}\end{array} \quad$ References \\
\hline
\end{tabular}

1<smiles>Nc1cc(C(=O)O)ccc1O</smiles>

3-amino-4-hydroxybenzoic acid

3-amino-4-hydroxybenzoic acid

2<smiles>O=C(O)c1cc(O)c(O)c(O)c1</smiles>

Gallic acid

Gallic acid

3<smiles>COc1cc(C(=O)O)cc(OC)c1O</smiles>

3, 4-dihydroxy-5 methoxybenzoic acid

4<smiles>O=C(O)c1cc2ccc(O)cc2oc1=O</smiles>

7-hydroxycoumarin-3carboxylic acid

7-hydroxycoumarin-3-carboxylic acid

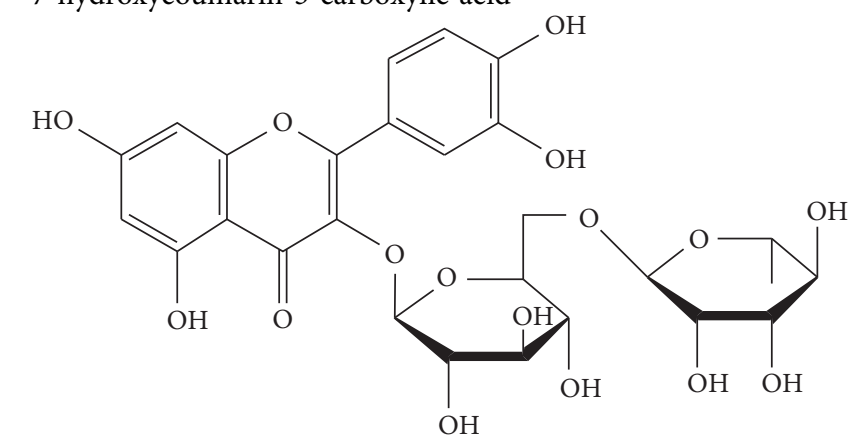
Rutin hydrate
2.1

Suzuki et al. [29]

3.5 nd nd $0.9 \quad$ Nayeem and Asdaq [30]

19.8 nd nd $7.2 \quad$ Wahdan et al. [32]

22.7 nd nd $2.1 \quad$ Karakas et al. [33] 
TABle 3: Continued.

\begin{tabular}{lll}
\hline $\mathrm{N}^{\circ} \quad$ Compounds and chemical structure compounds & Rt (min) $\begin{array}{c}\text { Concentration } \\
\text { (mg/g of dw) } \\
\text { CYH DCM MeOH }\end{array} \quad$ References \\
\hline
\end{tabular}

6<smiles>CCCCOC(=O)c1cc(O)c(O)c(O)c1</smiles>

Butyl gallate

7

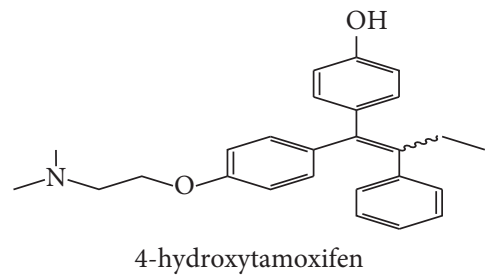

4-hydroxytamoxifen

8<smiles>COc1cc(O)cc(O)c1C(=O)/C=C/c1ccccc1</smiles>

Cardamonin

9<smiles>Oc1ccc(C2=Cc3ccc(O)cc3OC2)cc1</smiles>

Phenoxodiol

Phenoxodiol

10

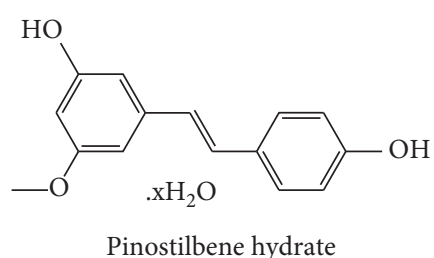

Pinostilbene hydrate

11

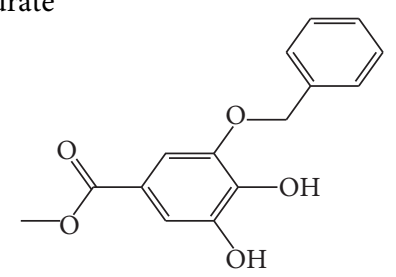

3-benzyloxy-4,5-dihydroxy-

benzoic acid methyl ester
43.0

nd

1.3

nd

Park et al. [34]

43.0

nd

1.1

nd

Shin and Choi [35]

44.2

nd

74.0

nd

Gonçalves et al. [36]

$44.3 \quad 0.3 \quad$ nd $\quad$ nd

Souza et al. [37]

44.6 1.2 nd $\quad$ nd Armstrong and Gredor [38]

45.0 nd 0.6 nd International Bureau [39] 
TABle 3: Continued.

\begin{tabular}{lll}
\hline $\mathrm{N}^{\circ} \quad$ Compounds and chemical structure compounds & Rt (min) $\begin{array}{c}\text { Concentration } \\
\text { (mg/g of dw) } \\
\text { CYH DCM MeOH }\end{array} \quad$ References \\
\hline
\end{tabular}

12<smiles>CCOC(=O)/C=C/c1ccccc1O</smiles>

Ethyl trans-2-

hydroxycinnamate

Ethyl trans-2-hydroxycinnamate

13<smiles>COc1cc(O)c2c(=O)cc(-c3ccc(O)cc3)oc2c1</smiles>

4', 5-dihydroxy-7-methoxyflavone

14<smiles>COc1cc(O)cc(/C=C/c2ccccc2)c1</smiles>

Pinosylvin monomethyl ether

Pinosylvin monomethyl ether

15<smiles>COc1cccc(-c2oc3ccc(OC)cc3c(=O)c2OC)c1</smiles>

$3,6,3^{\prime}$-trimethoxyflavone

3, 6, 3'-trimethoxyflavone

16<smiles>CC(C)=CC[C@@H](O)C1=CC(=O)c2c(O)ccc(O)c2C1=O</smiles>

45.3 nd 0.9 nd Weitkamp et al. [40]

$\begin{array}{llll}46.3 & 26.4 & 25.0 & \text { nd } \quad \text { Rudrapaul et al. [41] }\end{array}$

$\begin{array}{lllll}47.0 & 0.3 & 0.5 & \text { nd } & \text { Gabaston et al. [42] }\end{array}$

$48.0 \quad 3.2$ nd $\quad$ nd Shi et al. [44] 
TABLE 3: Continued.

\begin{tabular}{lll}
\hline $\mathrm{N}^{\circ} \quad$ Compounds and chemical structure compounds & Rt (min) $\begin{array}{c}\text { Concentration } \\
(\mathrm{mg} / \mathrm{g} \text { of dw) } \\
\text { CYH DCM MeOH }\end{array} \quad$ References \\
\hline
\end{tabular}

17

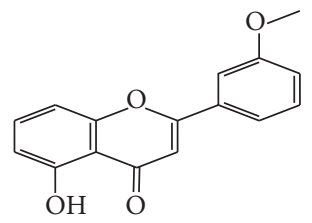

5-hydroxy-3'-

methoxyflavone
49.3

$3.5 \quad 55.5 \quad$ nd

Shafaghat et al. [45]
18

5-hydroxy-3'-methoxyflavone

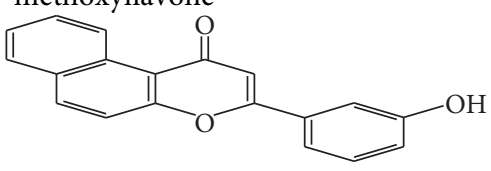

3'-hydroxy-b-naphthoflavone
49.8

7.9

50.4

nd

Yahyaoui et al. [24]

3'-hydroxy-b-naphthoflavone

CYH: cyclohexane; DCM: dichloromethane; dw: dry weight; MeOH: methanol. RT: retention time; nd: not detected.

In summary, these characteristic variations in the chemical composition between the different organic extracts could be due to the extractability of each solvent and the influence of environmental factors in the phenolic composition.

\subsubsection{Identification of the Volatile Compounds by GC-MS} Analysis. Gas chromatography coupled with mass spectrometry (GC-MS) was used to identify the volatile compounds in the organic extracts of $R$. crispus aerial part. Only two compounds (vitamin $\mathrm{E}$ and $\alpha$-sitosterol) were detected without derivatization. While $\alpha$-sitosterol was found in $\mathrm{CYH}$ and DCM extracts, the vitamin was detected only in the DCM one. Hence, in order to identify other volatile compounds, GC-MS derivatization was done to yield derivatized compounds with chromatographic characteristics and volatility. Overall, this was leading to the identification of 10 compounds in the three extracts (Table 4 ). These compounds were distributed as follows: 2 compounds in the CYH and DCM extracts, each, and 8 compounds in the $\mathrm{MeOH}$ extracts. Three compounds were detected in more than one extract. The characteristics of volatile compounds from different extracts indicate the presence of three families of organic compounds. Sterols, sugars, and phenolic acids. Some of these compounds were identified for the first time in $R$. crispus extracts, such as D-(-) fructopyranose, L-(-) arabitol, and 2, 5-dihydroxyacetophenone. Interestingly, the $\mathrm{MeOH}$ contained a variety of phenolic compounds, which are known for their antioxidant activity [59]. This finding was in agreement with the high antioxidant activity found in the current study. Moreover, several studies suggested the potent activity of some phenolic compounds against cancer cells, especially against MCF-7 and HCT-116 cell lines
$[25,60]$. Furthermore, $\beta$-sitosterol, the only compound detected with and without derivatization, is known for its antioxidant activity and its medicinal one (improve cholesterol levels in the human organism) [61, 62].

\subsection{Biological Activities}

3.4.1. AChE Inhibitory Activity. The anti-AChE activity of $R$. crispus aerial part has not been evaluated previously. Nevertheless, $\mathrm{MeOH}$ extract showed the highest inhibition $(83.7 \%)$ with an $\mathrm{IC}_{50}=31.6 \mu \mathrm{g} / \mathrm{mL}$ when compared to galanthamine, while CYH and DCM extract showed no AChE inhibitory activity (Table 5). This study showed that the antiAchE activity of the $\mathrm{MeOH}$ extract was higher than that of the other extracts obtained. Indeed, Patil et al. [63] proved that the presence of some phenolic compounds such as Rutin hydrate (with $\mathrm{IC}_{50}=1.1 \times 10^{3} \mu \mathrm{g} / \mathrm{ml}$ ) could contribute to the inhibition of AChE. In addition, the present results were better than those found by Ahmad et al. [62] when working with $R$. hastatus extracts. They found that the different extracts with different polarities (polar, moderately polar, and apolar) present an $\mathrm{IC}_{50}$ ranging between 75 and $1420 \mu \mathrm{g} / \mathrm{mL}$. Recent studies showed that there was a relation between antioxidant property and cholinesterase inhibitory activity [64]. This can validate our findings where we found a high correlation value between TPC and anti-AChE activity $\left(R^{2}=0.99\right)$.

3.4.2. Cytotoxic Activity. In this study, the cytotoxic effect of the different extracts of $R$. crispus against two cancer cell lines (HCT-116 and MCF-7) and its potential to inhibit their growth were evaluated. All the extracts were found active against both cell lines, with DCM extract more dominant, as 
TABle 4: Volatil compounds identified, by GC-MS, in the different extracts of $R$. crispus aerial parts.

\begin{tabular}{|c|c|c|c|c|c|c|}
\hline \multirow{2}{*}{$\mathrm{N}^{\circ}$} & \multirow{2}{*}{ Volatil compounds and chemical structure } & \multirow{2}{*}{ Rt (min) } & \multicolumn{3}{|c|}{ Peak area $\left(\times 10^{6}\right)$} & \multirow{2}{*}{ References } \\
\hline & & & $\mathrm{CYH}$ & DCM & $\mathrm{MeOH}$ & \\
\hline \multicolumn{7}{|c|}{ Without derivatization } \\
\hline 1 & & 26.95 & nd & 5.9 & nd & Farina et al. [48] \\
\hline
\end{tabular}

Vitamin E

2

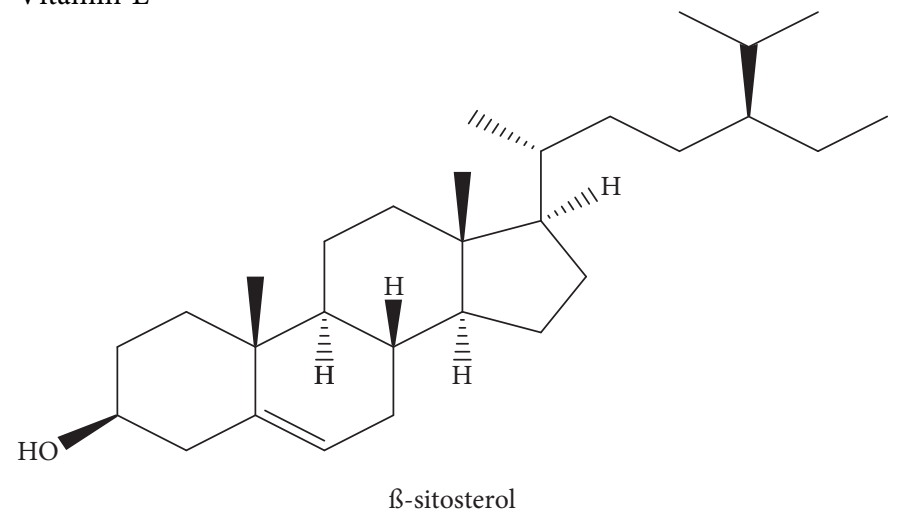

$\beta$-sitosterol

3<smiles>CC(=O)c1cc(O)ccc1O</smiles>

With derivatization
4

2, 5-dihydroxyacetophenone<smiles>O[C@H]1CO[C@@H](O)[C@@H](O)[C@H]1O</smiles>

$\beta^{-}{ }^{-}$-xylopyranose $\begin{array}{llll}13.40 & 3.6 & 0.7 & \text { nd }\end{array}$ Huang et al. [51] 
TABle 4: Continued.

\begin{tabular}{|c|c|c|c|c|c|c|}
\hline \multirow{2}{*}{$\mathrm{N}^{\circ}$} & \multirow{2}{*}{ Volatil compounds and chemical structure } & \multirow{2}{*}{ Rt (min) } & \multicolumn{3}{|c|}{ Peak area $\left(\times 10^{6}\right)$} & \multirow{2}{*}{ References } \\
\hline & & & $\mathrm{CYH}$ & DCM & $\mathrm{MeOH}$ & \\
\hline
\end{tabular}

5<smiles>OC[C@@H](O)C(O)[C@H](O)CO</smiles>

L-(-)-arabitol

L-(-)-arabitol

6

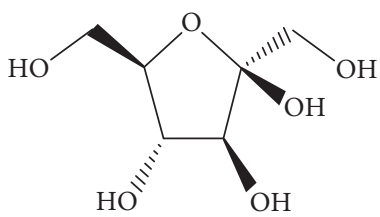

D-(-) Fructofuranose

D-(-) fructofuranose

7

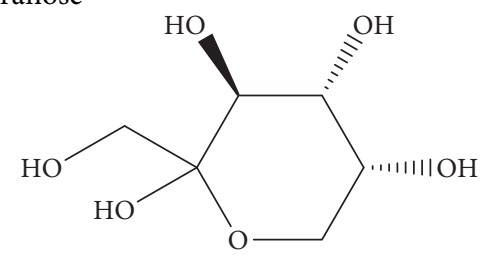

D-(-) fructopyranose

D-(-) fructopyranose

8<smiles>OC[C@H]1O[C@H](O)[C@H](O)[C@H](O)[C@H]1O</smiles>

D-glucose

D-glucose

9<smiles>O=C(O)c1cc(O)c(O)c(O)c1</smiles>

Gallic acid
15.27 nd nd $78.6 \quad$ Yu et al. [53]

15.33 nd nd $78.6 \quad$ Yu et al. [53]

16.42 nd nd $53.5 \quad$ Nguyen et al. [55]

Gallic acid 
TABLE 4: Continued.

\begin{tabular}{|c|c|c|c|c|c|}
\hline \multirow{2}{*}{$\mathrm{N}^{\circ}$} & \multirow{2}{*}{ Volatil compounds and chemical structure } & \multirow{2}{*}{$\mathrm{Rt}(\mathrm{min})$} & \multicolumn{2}{|c|}{ Peak area $\left(\times 10^{6}\right)$} & \multirow{2}{*}{ References } \\
\hline & & & CYH DCM & $\mathrm{MeOH}$ & \\
\hline
\end{tabular}

10<smiles>O[C@H]1[C@H](O)[C@H](O)[C@H](O)[C@@H](O)[C@H]1O</smiles>

Myo-inositol
17.17

nd nd

17.3

Maldonado et al. [56]
11

Myo-inositol

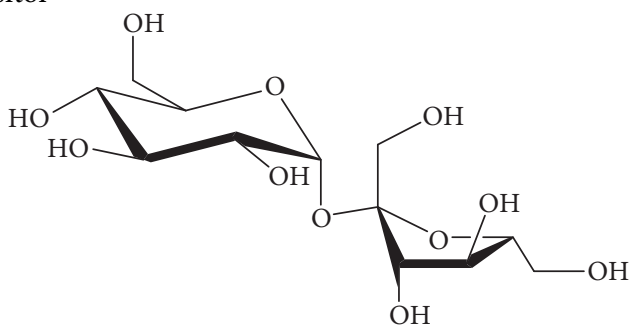

Sucrose

Sucrose

12

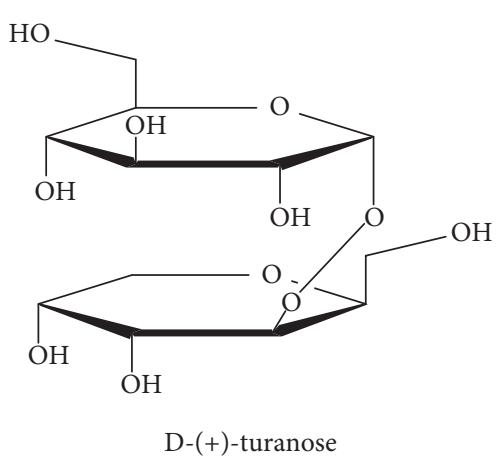

20.36 nd nd $51.1 \quad$ Durand et al. [57]

20.51 nd nd $7.4 \quad$ Pereira et al. [58]

D-(+)-turanose

CYH: cyclohexane; DCM: dichloromethane; $\mathrm{MeOH}$ : methanol. RT: retention time; nd: not detected.

Table 5: Anti-acetylcholinesterase activity of $R$. crispus extracts.

\begin{tabular}{lcc}
\hline \multirow{2}{*}{ Samples } & \multicolumn{2}{c}{ Anti-acetylcholinesterase activity } \\
& \% Inhibition $(50 \mu \mathrm{g} / \mathrm{mL})$ & $\mathrm{IC}_{50}(\mu \mathrm{g} / \mathrm{mL})$ \\
\hline $\mathrm{CYH}$ & $\mathrm{na}$ & $>50$ \\
$\mathrm{DCM}$ & $\mathrm{na}$ & $>50$ \\
$\mathrm{MeOH}$ & $83.7 \pm 2.2^{\mathrm{a}}$ & $31.6 \pm 3.7$ \\
Galanthamine & - & $1.2 \pm 0.1$ \\
\hline
\end{tabular}

CYH: cyclohexane; DCM: dichloromethane; $\mathrm{MeOH}$ : methanol. na: not active.

shown in Figure 2. When taking each cell line separately, a significant difference $(p \leq 0.05)$ was noticed between the different extracts in terms of effect against each cell line. The CYH extract has a weak effect against HCT-116 less with an inhibition that does not exceed $20 \%$, while it showed good activity against the MCF-7 cell line. Furthermore, the $\mathrm{MeOH}$ extract has almost an equal effect against both cell lines (HCT-116 and MCF-7) with inhibition of 58.3 and $57.3 \%$ at the concentration of $50 \mathrm{mg} / \mathrm{L}$, respectively. In addition, for both cell lines, HCT-116 and MCF-7, the DCM extract revealed the highest cytotoxic potential with almost 69.2 and $77.2 \%$ of inhibition, respectively. This inhibition may be due to the presence of some phenolic compounds, which are known for their important cytotoxic activities, especially cardamonin with $\mathrm{IC}_{50}$ equal to 8.1 and $8.6 \mu \mathrm{g} / \mathrm{mL}$, respectively, against the two cell lines (MCF-7 and HCT-116) [65]. Other studies suggested potent activity against cancer cells, including MCF-7 and HCT-116 cell lines, among which shikonin molecule $\left(\mathrm{IC}_{50}=0.83\right.$ and $0.53(\mu \mathrm{g} / \mathrm{ml})$ ), respectively [66], which confirms our obtained results. We also compared the results of our study with those found by Wang et al. [67]. They showed that methanolic extract of R. crispus species, collected from Rafha region, Kingdom of Saudi 


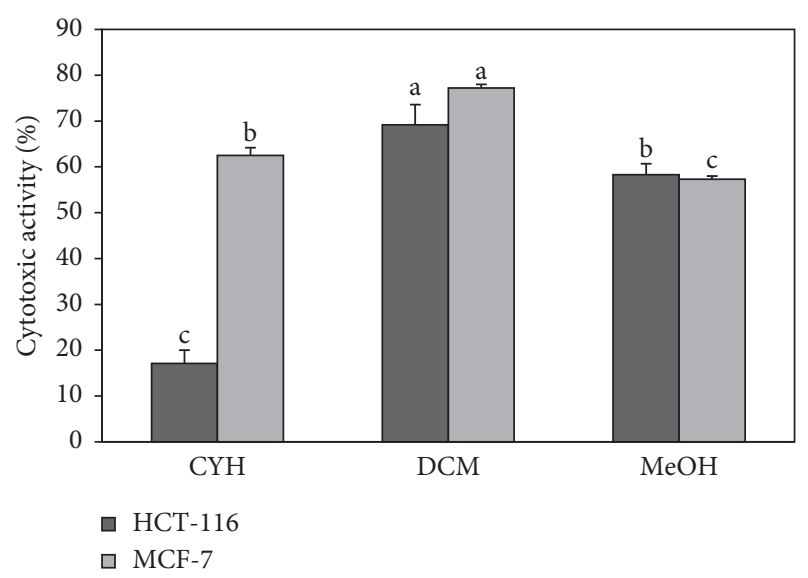

FIgUre 2: Cytotoxic activity of R. crispus extracts on MCF-7 and HCT-116 cancer cell lines. (CYH: cyclohexane; DCM: dichloromethane; $\mathrm{MeOH}$ : methanol). Data are the mean of three repetitions \pm SD. Different letters indicate significant differences according to Tukey test $(p \leq 0.05)$.

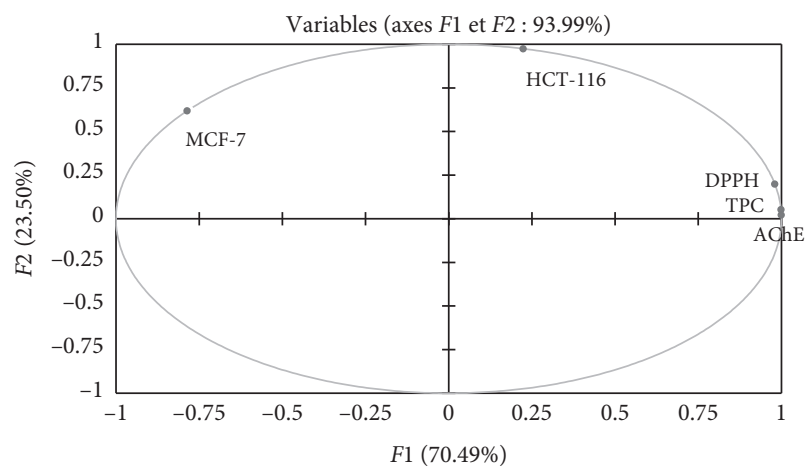

Figure 3: Principal components analysis loading plot of antioxidant and biological activities of $R$. crispus extracts. TPC: total phenolic content; AChE: antiacetylcholinesterase activity; DPPH: antioxidant activity; MCF-7: cytotoxicity 1; HCT-116: cytotoxicity 2.

Arabia, had no cytotoxic activity (0\%) against the MCF-7 cell line. In a previous study, Shaik and Raja [68] reported that the polysaccharide characterized from the aqueous extract of Polygonum equisetiforme (Polygonaceae) has low activity against both MCF-7 and HCT-116, with 11.3 and 14.5\%, respectively.

3.5. Principal Components Analysis (PCA). Principal component analysis was done to understand the relationship among the measured antioxidant, biological activities, and TPC. The various results of PCA are shown in Figure 3. The main components ( $F 1$ and $F 2$ ) explaining $93.99 \%$ of the total data variance. According to this analysis, the inertial axis was withheld, as shown in Table 6. The loadings in the PCA curve not only express the degree of correlation of the factors with the initial variables but also indicate the correlation between the different activities (DPPH, AChE, MCF-7, and HCT$116)$ and TPC. While the first principal component $(F 1)$
TABLE 6: Contribution of variable factors to the principal component's analysis (\%).

\begin{tabular}{lcc}
\hline & $F 1$ & $F 2$ \\
\hline Total phenolic content (TPC) & 27.5 & 0.2 \\
Radical scavenging activity (DPPH) & 26.5 & 2.9 \\
Anti-acetylcholinesterase activity (AChE) & 27.9 & 0.1 \\
Cytotoxic activity (MCF-7) & 17.0 & 27.8 \\
Cytotoxic activity (HCT-116) & 1.4 & 69.1 \\
\hline
\end{tabular}

TABLE 7: Correlations between variables and factors.

\begin{tabular}{lcc}
\hline & $F 1$ & $F 2$ \\
\hline Total phenolic content (TPC) & 0.99 & 0.052 \\
Radical scavenging activity (DPPH) & 0.98 & 0.19 \\
Anti-acetylcholinesterase activity (AChE) & 1.00 & 0.02 \\
Cytotoxic activity (MCF-7) & -0.79 & 0.62 \\
Cytotoxic activity (HCT-116) & 0.22 & 0.98 \\
\hline
\end{tabular}

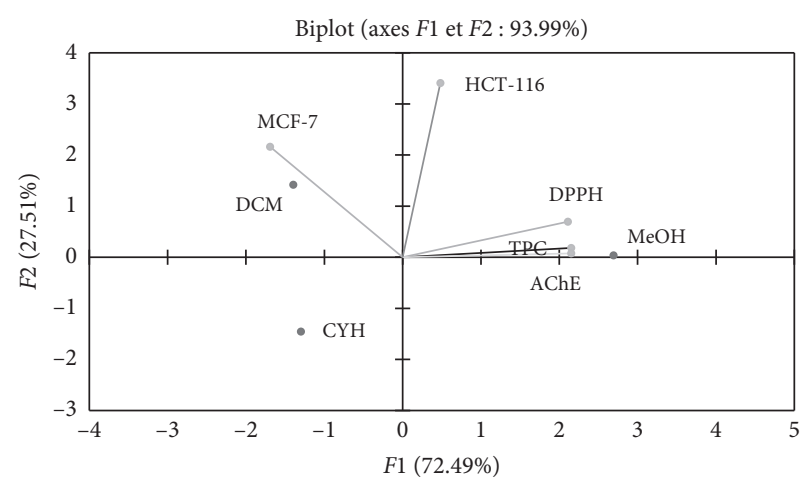

Figure 4: Principal components analysis biplot of antioxidant and biological activities of differents extracts of R. crispus. (CYH: cyclohexane; DCM: dichloromethane; $\mathrm{MeOH}$ : methanol).

correlated well with DPPH, AChE, and TPC having loadings $0.98,1.0$, and 0.99 , respectively, the second principal component $(F 2)$ was related to the cytotoxic activity with both cell lines (MCF-7 and HCT-116) with loadings of 0.62 and 0.98 , respectively (Table 7). Figure 3 also presented good correlations between AChE activity, DPPH radical scavenging activity, and TPC.

Using the biplot figure (Figure 4), it seems that the extract relative to TPC and biological activity were positioned according to its chemical composition. The $\mathrm{MeOH}$ extract with the highest TPC was located close to DPPH and AChE activity. Therefore, it may be to suggest that polyphenols compounds help to inhibit these two activities. Likewise, the DCM extract was located close to MCF-7. This extract contains several compounds at medium polarity with a major compound: cardamon is known according to the literature by its cytotoxic properties $[69,70]$.

\section{Conclusion}

Our findings revealed that the TPC and the antioxidant activity of $R$. crispus were higher compared with those of other species and varied with the polarity of the solvent of 
extraction. While a moderate correlation was found between the TPC, anti-AChE, and cytotoxic activities, there was a strong correlation between the TPC and antioxidant results of the different extracts. As a result of the HPLC-DAD analysis conducted on $R$. crispus extracts, our findings demonstrate that the dominant compounds belong to the cardamonin and flavone classes. Besides, GC-MS analysis showed that the $\mathrm{MeOH}$ extracts contain the majority of the volatile compounds which belong to the sugar class.

Based on the evidence of significant AChE inhibition and free radical scavenging on various samples of $R$. crispus, it can be inferred that our species may be the best source of antioxidants and anticholinesterase compounds. These important biological activities indicate that $R$. crispus could be a potential source of the active molecules intended for use in the pharmaceutical industry. Further work needs to be established to identify other molecules responsible for such activities using for example the flash chromatography.

\section{Data Availability}

We believe that ensuring that the data underlying the findings of a paper are publicly available wherever possible-as open as possible and as closed as necessary.

\section{Conflicts of Interest}

The authors declare that they have no conflicts of interest regarding the work described in this manuscript.

\section{Authors' Contributions}

Experiments and the manuscript writing were done by Mohamed Marouane Saoudi, under the guidance of the coauthors. Khaled Alouani and Bouajila Jalloul validated the experiments, proofread, and refined the manuscript to be ready for publication. Rami Rahmani performed the statistical analysis.

\section{Acknowledgments}

This work has been supported financially by the Tunisian Minister of Higher Education and Scientific Research, which provided a Ph.D. scholarship for the student Mohamed Marouane Saoudi.

\section{References}

[1] F. A. Matough, S. B. Budin, Z. A. Hamid, N. Alwahaibi, and J. Mohamed, "The role of oxidative stress and antioxidants in diabetic complications," Sultan Qaboos University Medical Journal, vol. 12, no. 1, pp. 556-569, 2012.

[2] L. Machu, L. Misurcova, J. Vavra Ambrozova et al., "Phenolic content and antioxidant capacity in algal food products," Molecules, vol. 20, no. 1, pp. 1118-1133, 2015.

[3] G. Gunalan, N. Myla, and R. Balabhaskar, "Research article in vitro antioxidant analysis of selected coffee bean varieties," Journal of Chemical and Pharmaceutical Research, vol. 4, no. 4, pp. 2126-2132, 2012.
[4] V. Lobo, A. Patil, A. Phatak, and N. Chandra, "Free radicals, antioxidants and functional foods: impact on human health," Pharmacognosy Reviews, vol. 4, no. 8, pp. 118-126, 2010.

[5] S. U. Rakesh, P. R. Patil, and S. R. Mane, "Use of natural antioxidants to scavenge free radicals: a major cause of diseases," International Journal of PharmTech Research, vol. 2, no. 2, pp. 1074-1081, 2010.

[6] S. S. Naphade, S. S. Khadabadi, S. L. Deore, N. S. Jagtap, and S. P. Hadke, "Antioxidant activity of different extracts of plant Tricholepis glaberrima DC (asteraceae)," International Journal of PharmTech Research, vol. 1, no. 3, pp. 502-505, 2009.

[7] O. Aiyegoro and A. Okoh, "Phytochemical screening and polyphenolic antioxidant activity of aqueous crude leaf extract of Helichrysum pedunculatum," International Journal of Molecular Sciences, vol. 10, no. 11, pp. 4990-5001, 2009.

[8] S. Mariem, F. Hanen, J. Inès, S. Mejdi, and K. Riadh, "Phenolic profile, biological activities and fraction analysis of the medicinal halophyte Retama raetam," South African Journal of Botany, vol. 94, pp. 114-121, 2014.

[9] M. Mohammadi-Sichani, P. Sadeghzadeh, and M. Madani, "Evaluation of antibacterial activity of extract of Rumex alveollatus leaf against Staphylococcus aureus and Pseudomonas aeruginosa," Zahedan Journal of Research in Medical Sciences, vol. 15, no. 6, pp. 58-61, 2013.

[10] L. Tavares, D. Carrilho, M. Tyagi et al., "Antioxidant capacity of macaronesian traditional medicinal plants," Molecules, vol. 15, no. 4, pp. 2576-2592, 2010.

[11] A.-L. Molan and A. M. Faraj, "The effects of condensed tannins extracted from different plant species on egg hatching and larval development of Teladorsagia circumcincta (nematoda: trichostrongylidae)," Folia Parasitologica, vol. 57, no. 1, pp. 62-68, 2010.

[12] M. Saleem, B. Ahmed, M. Karim et al., "Hepatoprotective effect of aqeous methanolic extract of Rumex dentatus in paracetamol-induced hepatotoxicity in mice," Bangladesh Journal of Pharmacology, vol. 9, no. 3, pp. 284-289, 2014.

[13] Q. C. Xie and Y. P. Yang, "Anti-proliferative of physcion 8-O$\beta$-glucopyranoside isolated from Rumex japonicus Houtt. on A549 cell lines via inducing apoptosis and cell cycle arrest," BMC Complementary and Alternative Medicine, vol. 14, no. 1, pp. 1-10, 2014.

[14] J. Ogweno Midiwo, A. Yenesew, B. F. Juma et al., "Bioactive compounds from some Kenyan ethnomedicinal plants: Myrsinaceae, Polygonaceae and Psiadia punctulata," Phytochemistry Reviews, vol. 1, no. 3, pp. 311-323, 2002.

[15] L. Ghosh, J. R. Gayen, S. Sinha, S. Pal, M. Pal, and B. P. Saha, "Antibacterial efficacy of Rumex nepalensis Spreng. roots," Phytotherapy Research, vol. 17, no. 5, pp. 558-559, 2003.

[16] S. Sahreen, M. R. Khan, R. A. Khan, and T. B. Hadda, "Evaluation of phytochemical content, antimicrobial, cytotoxic and antitumor activities of extract from Rumex hastatus D. don roots," BMC Complementary and Alternative Medicine, vol. 15, no. 1, pp. 1-6, 2015.

[17] A. Vasas, O. Orbán-Gyapai, and J. Hohmann, “The genus rumex: review of traditional uses, phytochemistry and pharmacology," Journal of Ethnopharmacology, vol. 175, pp. 198-228, 2015.

[18] Z. Maksimovíc, N. Kovačevíc, B. Lakušíc, and T. Ćebovíc, "Antioxidant activity of yellow dock (Rumex crispus L., Polygonaceae) fruit extract," Phytotherapy Research, vol. 25, no. 1, pp. 101-105, 2011.

[19] P. Feduraev, G. Chupakhina, P. Maslennikov, N. Tacenko, and L. Skrypnik, "Variation in phenolic compounds content and antioxidant activity of different plant organs from Rumex 
crispus L. and Rumex obtusifolius L. at different growth stages," Antioxidants, vol. 8, no. 7, 2019.

[20] J. G. Zaller, "Ecology and non-chemical control of Rumex crispus and R. obtusifolius (Polygonaceae): a review," Weed Research, vol. 44, no. 6, pp. 414-432, 2004.

[21] O. A. Idris, O. A. Wintola, and A. J. Afolayan, "Phytochemical and antioxidant activities of Rumex crispus L. in treatment of gastrointestinal helminths in eastern Cape province, south Africa," Asian Pacific Journal of Tropical Biomedicine, vol. 7, no. 12, pp. 1071-1078, 2017.

[22] T. Olckers, "Invasive species: vectors and management strategies," African Journal of Aquatic Science, vol. 29, no. 2, p. 287, 2004.

[23] E. Le Floc'h, L. Boulos, and E. Vela, "Rumex Crispus," Catalogue Synonymique Commenté de la Flore de Tunisie, Tunis, Tunisia, 2010.

[24] M. Yahyaoui, J. Bouajila, S. Cazaux, and M. Abderrabba, "The impact of regional locality on chemical composition, antioxidant and biological activities of Thymelaea hirsuta L. extracts," Phytomedicine, vol. 41, pp. 13-23, 2018.

[25] R. Rahmani, S. Beaufort, S. A. Villarreal-Soto, P. Taillandier, J. Bouajila, and M. Debouba, "Kombucha fermentation of African mustard (Brassica tournefortii) leaves: chemical composition and bioactivity," Food Bioscience, vol. 30, Article ID 100414, 2019.

[26] I. Coruh, A. Gormez, S. Ercisli, and M. Sengul, "Total phenolic content, antioxidant, and antibacterial activity of Rumex crispus grown wild in Turkey," Pharmaceutical Biology, vol. 46, no. 9, pp. 634-638, 2008.

[27] T. Ćebović, D. Jakovljević, Z. Maksimović, S. Djordjević, S. Jakovljević, and D. Četojević-Simin, "Antioxidant and cytotoxic activities of curly dock (Rumex crispus L., Polygonaceae) fruit extract," Vojnosanitetski Pregled, vol. 77, no. 3, pp. 308-316, 2020.

[28] A. A. Elzaawely, T. D. Xuan, and S. Tawata, "Antioxidant and antibacterial activities of Rumex japonicus HOUTT. aerial parts," Biological and Pharmaceutical Bulletin, vol. 28, no. 12, pp. 2225-2230, 2005.

[29] H. Suzuki, Y. Ohnishi, Y. Furusho, S. Sakuda, and S. Horinouchi, "Novel benzene ring biosynthesis from C3 and C4 primary metabolites by two enzymes," Journal of Biological Chemistry, vol. 281, no. 48, pp. 36944-36951, 2006.

[30] N. Nayeem and S. M. B. Asdaq, "Gallic acid: a promising lead molecule for drug development," Journal of Applied Pharmacy, vol. 08, no. 2, pp. 8-11, 2016.

[31] Z. Huyut, Ş. Beydemir, and I. Gülçin, “Antioxidant and antiradical properties of selected flavonoids and phenolic compounds," Biochemistry Research International, vol. 2017, Article ID 7616791, 10 pages, 2017.

[32] O. Wahdan, S. Aly Badr, and M. Abdelfattah, "Phytochemical analysis, antibacterial and anticancer activities of the physalis peruviana calyces growing in Egypt," Food \& Nutrition Journal, vol. 4, no. 1, pp. 1-6, 2019.

[33] F. P. Karakas, A. B. Yidirim, R. Bayram, M. Z. Yavuz, A. Gepdiremen, and A. U. Turker, "Antiproliferative activity of some medicinal plants on human breast and hepatocellular carcinoma cell lines and their phenolic contents," Tropical Journal of Pharmaceutical Research, vol. 14, no. 10, pp. 1787-1795, 2015.

[34] D. J. Park, H. J. Jung, C. H. Park, T. Yokozawa, and J. C. Jeong, "Root bark of paeonia suffruticosa extract and its component methyl gallate possess peroxynitrite scavenging activity and anti-inflammatory properties through NF- $\kappa \mathrm{B}$ inhibition in LPS-treated mice," Molecules, vol. 24, no. 19, 2019.
[35] S.-C. Shin and J.-S. Choi, "Effects of epigallocatechin gallate on the oral bioavailability and pharmacokinetics of tamoxifen and its main metabolite, 4-hydroxytamoxifen, in rats," AntiCancer Drugs, vol. 20, no. 7, pp. 584-588, 2009.

[36] L. M. Gonçalves, I. M. Valente, and J. A. Rodrigues, "An overview on cardamonin," Journal of Medicinal Food, vol. 17, no. 6, pp. 633-640, 2014.

[37] E. N. F. Souza, E. M. Williamson, and J. A. Hawkins, "Which plants used in ethnomedicine are characterized? phylogenetic patterns in traditional use related to research effort," Frontiers in Plant Science, vol. 9, pp. 1-12, 2018.

[38] C. P. Armstrong and A. J. Gregor, "Brief communications," Psychiatry, vol. 27, no. 1, pp. 69-72, 1964.

[39] V. P. Shipov, E. S. Pigarev, and E. I. Fedoros, "Benzene polycarboxylic acid compounds and their use as drug," United States Patent, Patent No: (US 9644074), 2017.

[40] P. Weitkamp, K. Vosmann, and N. Weber, "Highly efficient preparation of lipophilic hydroxycinnamates by solvent-free lipase-catalyzed transesterification," Journal of Agricultural and Food Chemistry, vol. 54, no. 19, pp. 7062-7068, 2006.

[41] P. Rudrapaul, M. Gruner, H. J. Knölker, and B. Dinda, "Flavones and triterpenes from the leaves of Vitex peduncularis," Indian Journal of Chemistry-Section B Organic and Medicinal Chemistry, vol. 54B, no. 2, pp. 279-282, 2015.

[42] J. Gabaston, T. Richard, S. Cluzet et al., "Pinus pinaster knot: a source of polyphenols against Plasmopara viticola," Journal of Agricultural and Food Chemistry, vol. 65, no. 40, pp. 88848891, 2017.

[43] M. Aritomi and T. Kawasaki, "Three highly oxygenated flavone glucuronides in leaves of Spinacia oleracea," Phytochemistry, vol. 23, no. 9, pp. 2043-2047, 1984.

[44] J. Shi, J. Ming, and W. Sun, "Passivation and chloride-induced corrosion of a duplex alloy steel in alkali-activated slag extract solutions," Construction and Building Materials, vol. 155, pp. 992-1002, 2017.

[45] A. Shafaghat, F. Pirfarshi, and M. Shafaghatlonbar, "Luteolin derivatives and antimicrobial activity of Achillea tenuifolia Lam. methanol extract," Industrial Crops and Products, vol. 62, pp. 533-536, 2014.

[46] Z. Kucekova, J. Mlcek, P. Humpolicek, O. Rop, P. Valasek, and P. Saha, "Phenolic compounds from Allium schoenoprasum, Tragopogon pratensis and Rumex acetosa and their antiproliferative effects," Molecules, vol. 16, no. 11, pp. 9207-9217, 2011.

[47] S. N. López, R. L. E. Furlan, and S. A. Zacchino, "Detection of antifungal compounds in Polygonum ferrugineum Wedd. extracts by bioassay-guided fractionation. Some evidences of their mode of action," Journal of Ethnopharmacology, vol. 138, no. 2, pp. 633-636, 2011.

[48] N. Farina, D. Llewellyn, I. Mgekn, and N. Tabet, "Vitamin E for Alzheimer's dementia and mild cognitive impairment (review) summary of findings for the main comparison," Cochrane Database of Systematic Reviews, vol. 4, no. 4, 2017.

[49] A. Sen, P. Dhavan, K. K. Shukla, S. Singh, and G. Tejovathi, "Analysis of IR, NMR and antimicrobial activity of $\beta$-sitosterol isolated from momordica charantia," Science Secure Journal of Biotechnology, vol. 1, no. 1, pp. 9-13, 2012.

[50] A. S. Bowman, S. O. Asare, and B. C. Lynn, "Matrix-assisted laser desorption/ionization time-of-flight mass spectrometry analysis for characterization of lignin oligomers using cationization techniques and 2, 5-dihydroxyacetophenone (DHAP) matrix," Rapid Communications in Mass Spectrometry, vol. 33, no. 8, pp. 811-819, 2019. 
[51] Y. Huang, N. Li, J.-B. Wan, D. Zhang, and C. Yan, "Structural characterization and antioxidant activity of a novel heteropolysaccharide from the submerged fermentation mycelia of Ganoderma capense," Carbohydrate Polymers, vol. 134, pp. 752-760, 2015.

[52] S. Shomo, H. Shifa, C. Senthilraja, M. G. Reddy, V. Paranidharan, and R. Velazhahan, "Analysis of metabolite profiles in leaf tissues of transgenic groundnut plants modified for resistance against tobacco streak virus," Biochemical and Cellular Archives, vol. 16, no. 2, pp. 245-250, 2016.

[53] S. Yu, X. Wang, T. Zhang et al., "Identification of a novel di-Dfructofuranose 1, 2': 2, 3' dianhydride (DFA III) hydrolysis enzyme from arthrobacter aurescens SK8.001," PLoS One, vol. 10, no. 11, pp. 1-18, 2015.

[54] D. F. McComsey and B. E. Maryanoff, "Improved synthesis of pseudo-.beta.-D-fructopyranose, a carbocyclic monosaccharide from (-)-quinic acid," The Journal of Organic Chemistry, vol. 59, no. 9, pp. 2652-2654, 1994.

[55] H. T. L. Nguyen, N. Panyoyai, V. D. Paramita, N. Mantri, and S. Kasapis, "Physicochemical and viscoelastic properties of honey from medicinal plants," Food Chemistry, vol. 241, pp. 143-149, 2018.

[56] J. Maldonado, Á. Fernández, and L. Cabeza, "Corrosion assessment of myo-inositol sugar alcohol as a phase change material in storage systems connected to fresnel solar plants," Molecules, vol. 24, no. 7, p. 1383, 2019.

[57] M. Durand, B. Porcheron, N. Hennion, L. Maurousset, R. Lemoine, and N. Pourtau, "Water deficit enhances C export to the roots in Arabidopsis thaliana plants with contribution of sucrose transporters in both shoot and roots," Plant Physiology, vol. 170, no. 3, pp. 1460-1479, 2016.

[58] C. Pereira, J. C. M. Barreira, R. C. Calhelha et al., "Is honey able to potentiate the antioxidant and cytotoxic properties of medicinal plants consumed as infusions for hepatoprotective effects?" Food \& Function, vol. 6, no. 5, pp. 1435-1442, 2015.

[59] M. D'Archivio, C. Filesi, R. Varì, B. Scazzocchio, and R. Masella, "Bioavailability of the polyphenols: status and controversies," International Journal of Molecular Sciences, vol. 11, no. 4, pp. 1321-1342, 2010.

[60] S. M. A. Moustafa, B. M. Menshawi, G. M. Wassel, K. Mahmoud, and M. M. Marwa, "Screening of some plants in Egypt for their cytotoxicity against four human cancer cell lines," International Journal of PharmTech Research, vol. 6, no. 3, pp. 1074-1084, 2014.

[61] N. Ammar, N. Ayoub, S. El-Ahmady, L. El-Kassem, and E. Zeid, "Phytochemical and cytotoxic studies of Rumex pictus forssk. and Rumex vesicarius L. (family Polygonaceae), growing in Egypt," European Journal of Medicinal Plants, vol. 10, no. 3, pp. 1-13, 2015

[62] S. Ahmad, F. Ullah, M. Ayaz, A. Sadiq, and M. Imran, "Antioxidant and anticholinesterase investigations of Rumex hastatus D. don: potential effectiveness in oxidative stress and neurological disorders," Biological Research, vol. 48, no. 1, pp. 1-8, 2015.

[63] D. N. Patil, S. A. Patil, S. Sistla, and J. P. Jadhav, "Comparative biophysical characterization: a screening tool for acetylcholinesterase inhibitors," PLoS One, vol. 14, no. 5, pp. e0215291-e0215328, 2019.

[64] B. Z. Kurt, I. Gazioğlu, E. Sevgi, and F. Sönmez, "Anticholinesterase, antioxidant, antiaflatoxigenic activities of ten edible wild plants from Ordu area, Turkey," Iranian Journal of Pharmaceutical Research: IJPR, vol. 17, no. 3, pp. 1047-1056, 2018.
[65] M. Abdelwahab, S. Sangi, H. Arafat, and E. Ragab, "New phytochemical constituent and bioactivities of Horwoodia dicksoniae and Rumex cyprius," Pharmacognosy Magazine, vol. 12, no. 47, pp. 165-170, 2016.

[66] I. Khlifi, E. A. Hayouni, S. Cazaux, R. Ksouri, and J. Bouajila, "Evaluation of in vitro biological activities: antioxidant; antiinflammatory; anticholinesterase; anti- xanthine oxidase, anti-superoxyde dismutase, anti- $\alpha$-glucosidase and cytotoxic of 19 bioflavonoids," Cellular and Molecular Biology, vol. 66, no. 1, p. 9, 2020.

[67] F. Wang, X. Yao, Y. Zhang, and J. Tang, "Synthesis, biological function and evaluation of shikonin in cancer therapy," Fitoterapia, vol. 134, pp. 329-339, 2019.

[68] T. A. Ibrahim and A. A. El-Hela, "Polysaccharide from the roots of polygonum equisetiforme Sibth. \& Sm: isolation, chemical composition, antioxidant potential and cytotoxic activity," International Journal of Pharma and Bio Sciences, vol. 3, no. 4, pp. 478-492, 2012.

[69] L. Berning, L. Scharf, E. Aplak et al., "In vitro selective cytotoxicity of the dietary Chalcone cardamonin (CD) on melanoma compared to healthy cells is mediated by apoptosis," PLoS One, vol. 14, no. 9, Article ID e0222267, 2019.

[70] J. Jin, S. Qiu, P. Wang et al., "Cardamonin inhibits breast cancer growth by repressing HIF- $1 \alpha$-dependent metabolic reprogramming," Journal of Experimental \& Clinical Cancer Research: CR, vol. 38, no. 1, p. 377, 2019. 